\title{
ANALISIS PENGARUH INFLASI, NILAI TUKAR RUPIAH, BI RATE, JUMLAH UANG BEREDAR, DAN INDEKS SHANGHAI STOCK EXCHANGE TERHADAP INDEKS SRI KEHATI DI BURSA EFEK INDONESIA PERIODE 2014-2019
}

\author{
Tri Wisnu Hermawan \\ Universitas Negeri Surabaya \\ triwisnu237@gmail.com \\ Purwohandoko \\ Universitas Negeri Surabaya \\ purwohandoko@unesa.ac.id
}

\begin{abstract}
This study is to explain the analysis of the influence of inflation, exchange rates, BI Rate, money supply, and Shanghai Stock Exchange index toward the Sri Kehati index on the Indonesia Stock Exchange (BEI) for the period 2014-2019. Data were analyzed by using multiple linear analysis techniques and use SPSS 18 as statistical analysis software. The sample type used is saturation samples so that there are 72 data taken monthly from 20142019. The results of this study indicate that inflation and exchange rate have a significant negative relationship to the Sri Kehati index. Meanwhile, the Shanghai Stock Exchange index has a significant positive relationship with the Sri Kehati index. The rest variable BI rate and money supply have no significant relationship to the Sri Kehati index. All independent variables simultaneously affect the Sri Kehati index. Based on the calculation the Adjusted $R$ square value is 0.279 which means that the movement of the Sri Kehati index is influenced by $28 \%$ by the variables in this study and $72 \%$ is explained by other variables outside this study. Therefore, further research is expected to add other potential independent variables. The implication from this research is that investors should pay more attention to the exchange rate, inflation, and the Shanghai Stock Exchange index before investing in the Sri Kehati index.
\end{abstract}

Keywords: BI rate; exchange rates; inflation; Shanghai Stock Exchange; Sri Kehati.

\section{PENDAHULUAN}

Berkembangnya zaman dan semakin majunya teknologi informasi saat ini tentunya menjadikan sebuah keuntungan yang bisa dimanfaatkan oleh kalangan masyarakat dan pihak-pihak tertentu untuk memperoleh informasi sebanyak-banyaknya. Salah satu keuntungan majunya teknologi informasi yang bisa dimanfaatkan dalam hal kegiatan seperti pembangunan nasional adalah adanya pasar modal. Suatu lembaga perantara di mana memiliki tugas dalam meningkatkan perekonomian karena dapat menjadi perantara golongan yang memerlukan modal dengan golongan yang kelebihan uang merupakan pengertian pasar modal (Tandelilin, 2010:26).

Berbagai jenis instrumen tersebut yang telah dikelompokkan dan umum diperjualbelikan di pasar modal seperti reksadana, instrumen derivatif, obligasi dan saham. Dari berbagai jenis instrumen pasar modal yang sudah disebutkan saham merupakan jenis instrumen pasar modal yang paling popular dibanding instrumen lainnya. Bukti kepemilikan suatu perusahaan yang dibuktikan dengan sertifikat dinamakan saham (Tandelilin, 2010).

Bursa Efek Indonesia (BEI) ialah institusi pasar modal milik Indonesia sebagai pelaksana dan mengadakan prosedur serta media menjembatani negosiasi jual beli saham, bertujuan memperjualbelikan saham mereka. Informasi perkembangan bursa ke publik lebih lengkapnya mengenai harga saham diinformasikan di media cetak dan elektronik oleh Bursa Efek Indonesia (BEI). Indeks Saham yaitu ukuran statistik dalam mengetahui keseluruhan pergerakan harga atas sekumpulan saham (IDX, 2018).

Bursa Efek Indonesia (BEI) hingga tahun 2020 mencatat 34 indeks saham, salah satu di antaranya adalah indeks Sri Kehati. Indeks Sri Kehati yaitu indeks khusus menilai perkembangan harga saham 25 
emiten dengan prestasi baik, selain itu indeks ini juga menekankan usaha-usaha secara berkelanjutan dan standar pemilihan perusahaan yang mempraktikkan dasar sustainable and responsible investment (IDX, 2018).

(SRI), serta sikap kesadaran terhadap lingkungan hidup, tata kelola, dan sosial perusahaan (Environmental, Social and Good Governance) (ESG) yang baik. Indeks ini diluncurkan oleh Yayasan Keanekaragaman Hayati Indonesia (KEHATI) pada 8 Juni 2009 dengan bekerja sama dengan PT BEI, keberadaan Yayasan KEHATI diharapkan mengumpulkan dan mengatur sumberdaya, kemudian diberikan dalam bentuk konsultasi, fasilitasi, dana hibah, dan sarana lain demi meningkatkan agenda konservasi keanekaragaman hayati Indonesia dan pendayagunaan yang sewajarnya dan berkelanjutan (Kehati, 2020). Indeks yang juga pertama di ASEAN yang menjadi indeks investasi hijau (green index). Indeks ini dapat menjadikan patokan investor maupun manajer investasi menentukan perusahaan publik (CRMS, 2020).

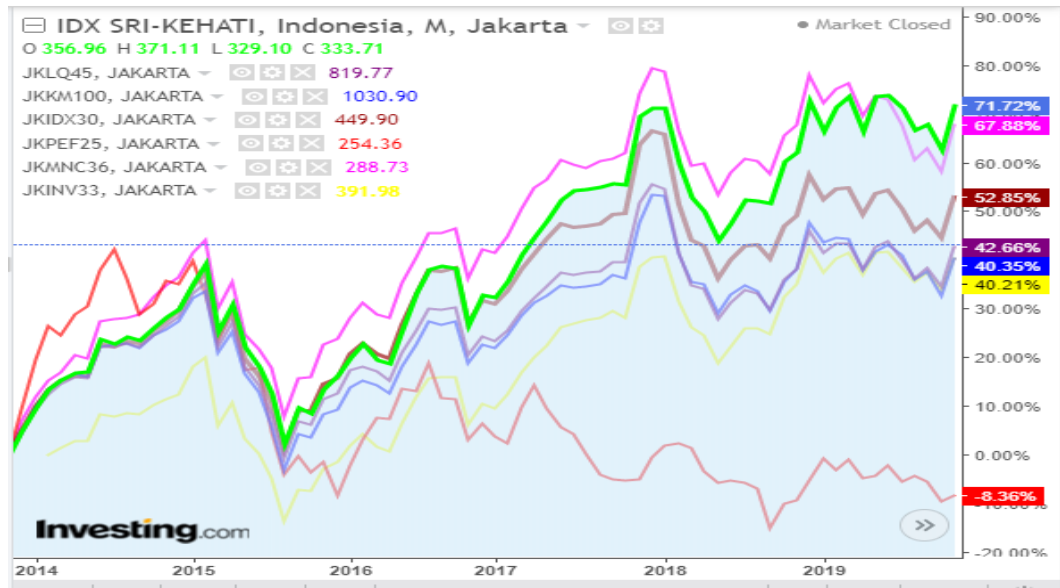

Sumber: Investing.com (2019)

Gambar 1. PERGERAKAN BEBERAPA INDEKS DI INDONESIA TAHUN 2014-2019

Gambar 1 menunjukkan pergerakan indeks-indeks menunjukkan bahwa terjadi fluktuasi dan peningkatan yang hampir sama. Namun pada tahun 2014 indeks harga saham domestik berhasil mencatat rekor indeks tertinggi sepanjang sejarah dan tercatat keempat tertinggi dari bursa-bursa utama dunia dan regional, hal ini dapat terjadi karena adanya optimisme dari investor terhadap pelaksanaan pemilihan umum (Pemilu) sehingga investor tetap bertransaksi di pasar modal Indonesia. (Detikfinance, 2014).

Tabel 1.

HISTORICAL DATA BEBERAPA INDEKS DI BURSA EFEK INDONESIA 2014-2019

\begin{tabular}{lccccc}
\hline \multirow{2}{*}{ Indeks } & \multicolumn{3}{c}{ Harga Saham 2014-2019 } & \multirow{2}{*}{ Perubahan \% } \\
& Tertinggi & Terendah & Selisih & Rata-rata & \\
\hline Sri Kehati & 422.73 & 224.10 & 198.63 & 327.97 & 71.72 \\
LQ45 & $1,132.92$ & 660.81 & 472.11 & 913.78 & 42.66 \\
Kompas 100 & $1,421.95$ & 830.53 & 591.42 & $1,159.61$ & 40.35 \\
IDX 30 & 621,46 & 342,07 & 279,39 & 488,93 & 52,85 \\
PEFINDO & 519,47 & 298,49 & 220,98 & 385,63 & $-8,36$ \\
MNC36 & 386,00 & 205,17 & 180,83 & 306,67 & 67,88 \\
Investor33 & 492,00 & 270,38 & 221,62 & 396,46 & 40,21 \\
\hline Sun
\end{tabular}

Tabel 1 menunjukkan beberapa indeks yang tercatat di IDX dikarenakan terdapat banyak indeks yang tercatat maka diambil sebagian indeks yang memiliki likuiditas tinggi dan sebagian menjalin kerjasama dengan perusahaan media serta memiliki kapitalisasi pasar yang besar sebagai perbandingan. Dapat 
Tri Wisnu Hermawan. Analisis Pengaruh Inflasi, Nilai Tukar Rupiah, BI Rate, Jumlah Uang Beredar, dan Indeks Shanghai Stock Exchange terhadap Indeks Sri Kehati di Bursa Efek Indonesia Periode 20142019

dilihat bahwa secara historis perubahan (\%) pergerakan indeks Sri Kehati dari tahun 2014-2019 memiliki perubahan tertinggi sebesar 71,72\%. Indeks Sri Kehati memiliki keunikan dari indeks-indeks lainnya yaitu indeks ini memiliki karakter di mana perusahaan bisa terdaftar dalam indeks ini melewati tahapan seleksi yang melihat aspek kepeduliannya terhadap lingkungan hidup, tidak hanya melihat dari kapitalisasi pasar yang besar (Wannabe, 2012). Dari data dan fenomena yang sudah dijelaskan di atas, maka indeks Sri Kehati dijadikan sebagai objek penelitian ini.

Faktor-faktor yang berpengaruh dalam proses pembentukan harga saham dapat diketahui dari dalam dan luar negeri. Jumlah uang beredar, nilai tukar, suku bunga, dan inflasi adalah sumber dari dalam negeri. Sementara faktor eksternal yang dapat memengaruhi adalah indeks global salah satunya seperti indeks Shanghai Stock Exchange. Faktor pertama yang memengaruhi indeks Sri Kehati yaitu inflasi. Peningkatan nilai secara umum dan berkelanjutan dalam tempo tertentu adalah inflasi dalam pengertian secara sederhana. Dengan adanya inflasi yang tinggi mengakibatkan proses produksi perusahaan menjadi terganggu karena meningkatnya harga barang. Dengan begitu akan menurunkan jumlah produksi perusahaan yang berimbas pada menurunnya laba. Investor melakukan transaksinya lebih berhati-hati dengan inflasi yang tinggi, menghindari risiko-risiko akibat inflasi tinggi penanam modal cenderung menunggu menanamkan modalnya sampai situasi perekonomian membaik Pada akhirnya investor akan merasa enggan untuk menempatkan dananya pada perusahaan karena menunggu keadaan perekonomian kondusif. Hal ini mengakibatkan menurunnya harga saham dan indeks harga saham (Manurung, 2016). Hasil penelitian Manurung (2016) telah membuktikan bahwa inflasi berpengaruh signifikan negatif terhadap IHSG. Sebaliknya Sari (2015) menyatakan bahwa inflasi berpengaruh signifikan positif terhadap IHSG. Berbeda menurut Puspita \& Aji (2018), inflasi tidak berpengaruh terhadap Indeks Kompas 100.

Faktor kedua yang memengaruhi Indeks Sri Kehati yaitu Suku Bunga. Dalam menanamkan modalnya investor pada umumnya mempertimbangkan besar kecilnya suku bunga. Saat suku bunga tabungan tinggi penanam modal akan cenderung menempatkan dananya di bank, dengan harapan pengembalian atas dana tabungan yang besar. Pemilik modal kemungkinan memindahkan dananya dalam bentuk deposito berjangka dibandingkan menyimpan dananya di pasar modal jika tingkat bunga deposito atau tabungan mengalami peningkatan dengan alasan tingkat keuntungan dan risiko yang kecil. Dampak kurang baik akan dirasakan pasar modal di mana permintaan saham berkurang dan akibatnya harga saham juga melemah serta diikuti menurunnya indeks harga saham (Fordian, 2016). Hasil penelitian Putri, et al,. (2015) telah membuktikan bahwa tingkat suku bunga berpengaruh signifikan negatif terhadap IHSG. Sebaliknya Nijam, et al,. (2015) menyatakan bahwa dari pengamatan indeks pasar saham secara signifikan berhubungan positif dengan suku bunga. Berbeda menurut Zabidi \& Asandimitra (2018) suku bunga tidak mempunyai efek pada IHSG.

Faktor ketiga yang memengaruhi Indeks Sri Kehati yaitu nilai tukar (kurs). Nilai tukar atau dikenal dengan kurs ialah suatu perbandingan mata uang asing (dollar) dengan mata uang lain (rupiah). Kurs memiliki peranan yang sangat esensial agar stabilitas moneter tercapai dan membantu aktivitas ekonomi. Ketika nilai tukar rupiah terhadap dollar menguat (apresiasi) ini mengindikasikan perekonomian dalam negeri dalam kondisi yang bagus. Sementara di saat nilai tukar rupiah melemah (depresiasi), barang impor tidak banyak yang mampu dibeli khususnya bagi perusahaan yang mayoritas bahan baku produksinya berasal dari hasil impor (Utami \& Herlambang, 2016). Dengan bahan baku impor yang mahal menjadikan produksi menjadi terhambat dan menurunkan laba perusahaan. Hal ini berdampak kurang baik pula terhadap harga saham perusahaan yang menimbulkan melemahnya pergerakan indeks harga saham (Prahesti \& Parmita, 2020). Hasil penelitian Utami \& Herlambang (2016) telah membuktikan bahwa nilai tukar memiliki efek positif terhadap Indeks JII. Sebaliknya, Widyasa \& Worokinasih (2018) menyatakan bahwa nilai tukar rupiah terhadap dollar berpengaruh signifikan dan berpengaruh negatif terhadap ISSI. Berbeda menurut Sari (2015) nilai tukar rupiah pada dollar tidak berpengaruh signifikan terhadap IHSG.

Faktor keempat memengaruhi Indeks Sri Kehati yaitu jumlah uang beredar. Total uang yang diedarkan bank sentral lalu berada di dalam masyarakat (perekonomian) dalam bentuk kertas dan logam ialah 
jumlah uang beredar. Jumlah uang yang diedarkan bank sentral meningkat, maka dana yang dipegang oleh masyarakat akan meningkat. Permintaan masyarakat akan uang terbagi menjadi tiga tujuan yaitu transaksi, berjaga-jaga dan spekulasi. Kondisi ekonomi modern dan berkembangnya lembaga keuangan, menjadikan tujuan penggunaan uang untuk spekulasi telah dilakukan masyarakat dengan cara menyimpan atau membeli surat-surat berharga seperti treasury bill, saham perusahaan, dan obligasi pemerintah (Sukirno, 2010:301). Di saat ketersediaan dana untuk spekulasi meningkat, maka meningkatnya permintaan akan saham cukup tinggi. Dampaknya terjadi peningkatan harga saham dan diikuti meningkatnya indeks harga saham (Prahesti \& Paramita, 2020). Hasil penelitian Qurochman (2017) telah membuktikan bahwa jumlah uang beredar berpengaruh signifikan positif terhadap indeks harga saham. Sebaliknya Otorima \& Kesuma (2016) menyatakan bahwa jumlah uang beredar berpengaruh negatif terhadap IHSG. Berbeda menurut Kusuma \& Badjra (2016) jumlah uang beredar tidak berpengaruh signifikan terhadap IHSG.

Faktor kelima yang memengaruhi Indeks Sri Kehati yaitu indeks Shanghai Stock Exchange yang digunakan sebagai indikator paling sering untuk menilai kinerja pasar Shanghai Stock Exchange. Indeks Shanghai Stock Exchange dapat menggambarkan kondisi perekonomian China. Indonesia dan China sendiri memiliki hubungan kerja sama yang kuat di bidang ekspor dan impor. Dalam hal impor barang Indonesia sangat membutuhkan barang-barang yang berasal dari China, terbukti berdasarkan data BPS selama beberapa tahun terakhir yaitu 2018, 2017, dan 2016 presentase impor dan ekspor dari China adalah yang tertinggi dibanding negara Asia lainnya, impor tahun 2018 sebesar 32,17\%, tahun 2017 sebesar 30,81\%, tahun 2016 sebesar 31,16\% (BPS, 2020c, data diolah). Sementara ekspor tahun 2018 sebesar 20,96\%, tahun 2017 sebesar 19,36\%, tahun 2016 sebesar 17,04\% (BPS, 2020b, data diolah). Naiknya Indeks Shanghai Stock Exchange dapat mengindikasikan bahwa perekonomian China baik. Pertumbuhan ekonomi China mampu menaikkan kemajuan ekonomi Indonesia dengan arus modal masuk dan ekspor di Indonesia. Ketika perekonomian di Indonesia dalam kondisi baik, banyak investor terdorong membeli saham perusahaan di pasar modal Indonesia. Dampaknya permintaan saham tinggi, kemudian membuat harga saham dan indeks harga saham ikut bergerak naik (Prahesti \& Parmita, 2020). Hasil penelitian Bery \& Worokinasih (2018) telah membuktikan bahwa Indeks Shanghai berpengaruh positif pada IHSG dengan naiknya Indeks Shanghai memberi pengaruh dengan naiknya IHSG. Sebaliknya Anggraini \& Nurhadi (2019) menyatakan bahwa Indeks Shanghai berpengaruh signifikan negatif pada IHSG. Berbeda menurut Lusiana (2020) Indeks Shanghai tidak berpengaruh pada IHSG.

Penelitian ini bertujuan memeriksa hubungan sebab akibat variabel independen nilai tukar, indeks Shanghai Stock Exchange, suku bunga (BI Rate), jumlah uang beredar dan inflasi terhadap variabel dependen indeks Sri Kehati.

\section{KAJIAN PUSTAKA DAN PENGEMBANGAN HIPOTESIS}

\section{Random Walk Theory}

Riset oleh Kendall (1953) dalam (Samsul, 2006:269) hasilnya menyatakan bahwa secara acak (random walk) saham bergerak yang menjadikan pola harga saham tidak dapat diprediksi (unpredictable). Informasi baru yang akan diterima memengaruhi bergeraknya harga saham secara acak, kapan informasi baru tersebut akan diterima juga tidak diketahui sehingga laporan baru dan harga saham itu disebut unpredictable (Samsul, 2006:296). Teori Random Walk dalam penelitian ini digunakan guna menjelaskan pengaruh inflasi, suku bunga, nilai tukar rupiah dan jumlah uang beredar terhadap indeks harga saham Sri Kehati.

\section{Contagion Effect}

Suatu efek yang timbul disebabkan adanya perubahan kondisi ekonomi suatu negara sehingga berdampak pada negara lainnya, baik regional maupun non-regional disebut Contagion effect atau teori domino modern. Perubahan keadaan ekonomi yang cenderung relatif dan berbeda yang kemudian dirasakan setiap negara disebabkan karena adanya interaksi dan kerjasama di bidang ekonomi negara tersebut (Kusumawati \& Asandimitra, 2017). Hal ini menunjukkan bahwa situasi perekonomian negara lain dapat menjadi bagian penentu dari status perekonomian suatu negara. Menurut penelitian Bank 
Tri Wisnu Hermawan. Analisis Pengaruh Inflasi, Nilai Tukar Rupiah, BI Rate, Jumlah Uang Beredar, dan Indeks Shanghai Stock Exchange terhadap Indeks Sri Kehati di Bursa Efek Indonesia Periode 20142019

Dunia, krisis di dunia tahun 2008 disebabkan terutama oleh adanya pola hubungan ekonomi sesama negara sehingga memicu contagion effect negara lain (Robiyanto \& Hartanto, 2018). Pengaruh indeks Shanghai Stock Exchange terhadap indeks harga saham Sri Kehati di penelitian ini dijelaskan dengan teori contagion effect.

\section{Indeks Sri Kehati}

Menurut (Sugiyono, 2017:39) variabel kriteria, output, konsekuen biasa disebut variabel dependen. Variabel dependen (Y) dalam penelitian ini berupa Indeks Sri Kehati sebuah indeks harga saham berisi 25 emiten tercatat di Bursa Efek Indonesia (BEI) hasil kerja sama dengan Yayasan Keanekaragaman Hayati Indonesia (KEHATI). Data yang digunakan merupakan data sekunder harga penutupan bulanan indeks Sri Kehati rentang waktu pengamatan Januari 2014 sampai Desember 2019 yang diterbitkan di website resmi investing.com. Menurut (Puspita \& Aji, 2018), perhitungan perubahan pergerakan Indeks dapat dihitung menggunakan rumus (1).

Indeks Sri Kehati $=\frac{\text { Sri Kehati }_{t}-\text { Sri Kehati }_{t-1}}{\text { Sri Kehati }_{t-1}} X 100 \%$

Keterangan:

Sri Kehati $\mathrm{i}_{\mathrm{t}}$ Indeks Sri Kehati periode $\mathrm{t}$

Sri Kehati $\mathrm{t}_{-1}=$ Indeks Sri Kehati periode $\mathrm{t}-1$

\section{Inflasi}

Kenaikan harga barang dan jasa secara berkelanjutan adalah pengertian inflasi secara umum atau diartikan secara menyeluruh nilai uang menurun, semakin tinggi kenaikan harga semakin turun nilai uang (Manurung, 2016). Data statistik bulanan inflasi digunakan rentang waktu pengamatan antara Januari 2014 sampai Desember 2019 yang diterbitkan di website resmi Badan Pusat Statistik. Menurut Rokhim (2014) dalam (Suriyani \& Sudiarta, 2018) inflasi dapat dihitung menggunakan rumus (2).

Inflasi $_{\mathrm{t}}=\frac{\text { Inflasi }_{\mathrm{t}}-\text { Inflasi }_{\mathrm{t}-1}}{\text { Inflasi }_{\mathrm{t}-1}} \times 100 \%$

Keterangan:

Inflasi $\mathrm{i}_{\mathrm{t}}=$ Inflasi periode $\mathrm{t}$

Inflasi $_{\mathrm{t}-1}=$ Inflasi periode $\mathrm{t}-1$

\section{Nilai Tukar}

Menurut Pratikno (2009) dalam (Manurung, 2016) Nilai tukar rupiah adalah perbandingan nilai atas harga rupiah dengan harga mata uang asing, masing-masing negara mempunyai nilai tukar mata uangnya yang menjadikan perbandingan nilai suatu mata uang dengan negara lain yang disebut kurs valuta asing. Kurs tengah rupiah terhadap dollar digunakan sebagai data penelitian menggunakan data statistik bulanan rentang waktu pengamatan Januari 2014 sampai Desember 2019 yang diterbitkan oleh website resmi Bank Indonesia. Menurut (Puspita \& Aji, 2018), perhitungan nilai tukar dapat dihitung menggunakan rumus (3).

Kurs $=\frac{\text { Kurs Tengah }_{\mathrm{t}}-\text { Kurs Tengah }_{\mathrm{t}-1}}{\text { Kurs Tengah }_{\mathrm{t}-1}} X 100 \%$

Keterangan:

Kurs Tengah ${ }_{\mathrm{t}}=$ Kurs Tengah periode $\mathrm{t}$

Kurs Tengah $\mathrm{t}_{\mathrm{t}-1}=$ Kurs Tengah periode $\mathrm{t}-1$

\section{BI Rate}

Total bunga yang dibayarkan per unit waktu yang disebut sebagai persentase dari total yang dipinjamkan adalah suku bunga (Samuelson \& Nordhaus, 2004:190). Data statistik bulanan BI Rate selama rentang waktu pengamatan Januari 2014 sampai Desember 2019 yang diterbitkan oleh website 
resmi Bank Indonesia. Menurut (Puspita \& Aji, 2018) perhitungan suku bunga menggunakan rumus (4).

BI Rate $=\frac{\text { BI Rate }_{t}-\text { BI Rate }_{t-1}}{\text { BI Rate }_{t-1}} X 100 \%$

Keterangan:

BI Rate $_{\mathrm{t}}=\mathrm{BI}$ Rate periode $\mathrm{t}$

BI Rate $_{\mathrm{t}-1}=\mathrm{BI}$ Rate periode $\mathrm{t}-1$

\section{Jumlah Uang Beredar}

Jumlah uang beredar sendiri ialah seluruh bentuk uang yang beredar dalam perekonomian, yaitu uang giral dalam bank-bank umum ditambah total mata uang beredar (Sukirno, 2010). Data yang digunakan ialah data statistik bulanan selama rentang waktu pengamatan Januari 2014 sampai Desember 2019 yang diterbitkan oleh website resmi Badan Pusat Statistik (BPS) (BPS, 2020a). Menurut Nellawati dan Isbanah (2014) dalam (Yulianti \& Purwohandoko, 2019) perhitungan jumlah uang beredar dihitung menggunakan rumus (5).

$\mathrm{JUB}=\frac{\mathrm{JUB}_{\mathrm{t}}-\mathrm{JUB}_{\mathrm{t}-1}}{\mathrm{JUB}_{\mathrm{t}-1}} X 100 \%$

Keterangan:

$\mathrm{JUB}_{\mathrm{t}}=\mathrm{JUB}$ periode $\mathrm{t}$

$\mathrm{JUB}_{\mathrm{t}-1}=\mathrm{JUB}$ periode $\mathrm{t}-1$

\section{Indeks Shanghai Stock Exchange}

Indeks Shanghai Stock Exchange merupakan sebuah pasar saham yang diperdagangkan di bursa saham terbesar di Republik Rakyat China. Indeks ini diluncurkan dan dikenalkan pertama kali pada 15 Juli 1991 di mana merupakan indeks statistik otoritatif yang banyak dicontoh di dalam maupun di luar negeri untuk menilai prestasi pasar modal China (Lusiana, 2020). Data diukur dengan menggunakan data statistik bulanan selama rentang waktu pengamatan Januari 2014 sampai Desember 2019 yang diterbitkan oleh website investing.com. Menurut Mie dan Agustina (2014) dalam (Lusiana, 2020) pengukuran indeks Shanghai menggunakan data perubahan setiap bulannya dengan rumus (6).

$S S E=\frac{\mathrm{SSE}_{\mathrm{t}}-\mathrm{SSE}_{\mathrm{t}-1}}{\mathrm{SEE}_{\mathrm{t}-1}} \times 100 \%$

Keterangan:

$\mathrm{SSE}_{\mathrm{t}}=\mathrm{SSE}$ periode $\mathrm{t}$

$\mathrm{SSE}_{\mathrm{t}-1}=\mathrm{SSE}$ periode $\mathrm{t}-1$

\section{Hubungan antar Variabel}

Bagi para investor maupun masyarakat kenaikan yang terjadi pada tingkat inflasi merupakan sinyal negatif. Inflasi sendiri diartikan sebagai adanya tren harga jasa dan barang mengalami peningkatan secara berkelanjutan. Salah satu faktor penting yang dipertimbangkan para investor sebelum berinvestsi di suatu saham perusahaan adalah inflasi. Pemerintah tentunya berusaha keras untuk menstabilkan tingkat inflasi, karena apabila laju inflasi tidak dikendalikan akan memberikan dampak bagi negara. Inflasi tinggi tentunya memengaruhi kemampuan beli masyarakat dan menghambat penjualan yang kemudian memengaruhi keuntungan perusahaan. Profitabilitas perusahaan yang melemah menyebabkan penanam modal mengambil kembali sahamnya untuk kemudian mencari investasi yang lebih menguntungkan dan berakibat pada melemahnya harga saham. Akibat menurunnya harga saham, indeks harga saham juga turun (Puspita \& Aji, 2018). Penelitian Maimuna (2017) menjelaskan inflasi berpengaruh negatif signifikan terhadap indeks harga saham. Naiknya harga barang dan jasa membuat investor berfikir ulang untuk berinvestasi guna menghindari risiko. Hal ini dapat terjadi pada Indeks Sri Kehati. 
Tri Wisnu Hermawan. Analisis Pengaruh Inflasi, Nilai Tukar Rupiah, BI Rate, Jumlah Uang Beredar, dan Indeks Shanghai Stock Exchange terhadap Indeks Sri Kehati di Bursa Efek Indonesia Periode 20142019

H1: Inflasi berpengaruh negatif terhadap indeks harga saham Sri Kehati di Bursa Efek Indonesia periode 2014-2019.

Perbandingan mata uang suatu negara dengan mata uang negara lain disebut nilai tukar. Jumlah permintaan dan penawaran akan suatu mata uang dari waktu ke waktu dapat menjadi faktor penyebab nilai tukar mengalami fluktuasi (Puspita \& Aji, 2018). Nilai tukar merupakan indikator penting bagi suatu perusahaan dalam kaitannya perdagangan antar negara atau proses ekspor dan impor suatu negara. Dollar amerika merupakan nilai tukar yang sering digunakan. Harga bahan mentah impor menjadi tinggi apabila rupiah mengalami pelemahan terhadap dollar amerika yang berdampak terjadinya penurunan profitabilitas dan harga saham perusahaan. Imbasnya indeks harga saham juga melemah (Zabidi \& Asandimitra, 2018). Penelitian Haider (2018) menunjukkan nilai tukar berpengaruh positif signifikan terhadap indeks harga saham. Apabila mata uang suatu negara mengalami depresiasi investor akan berfikir ulang untuk melakukan investasi guna menghindari risiko melemahnya nilai mata uang suatu negara. Dengan demikian indeks harga saham mengalami penurunan.

H2: Nilai tukar berpengaruh positif terhadap indeks harga saham Sri Kehati di Bursa Efek Indonesia periode 2014-2019.

Menurut Case and Fair (2004:167) dalam (Otorima \& Kesuma, 2016), pemenuhan bunga pinjaman tahunan yang dinyatakan sebagai persentase dari pinjaman disebut tingkat suku bunga, jumlah bunga yang diperoleh pertahun dibagi dengan total pinjaman adalah penjelasan persentase. Kondisi pasar modal dapat dipengaruhi tingkat suku bunga yang berubah. Kenaikan pada suku bunga memengaruhi keinginan penanam modal untuk lebih menyimpan uangnya di bank konvensional. Apalagi menabung uang dalam bentuk deposito memiliki risiko yang kecil bahkan hampir tidak ada. Hal ini dapat menurunkan harga saham dan juga indeks harga saham. Penelitian Sari (2015) menunjukkan suku bunga berpengaruh negatif signifikan terhadap harga saham. Peningkatan suku bunga membuat penanam modal berfikir ulang untuk menginvestasikan dananya. Apabila investor memilih menyimpan uangnya di bank maka pasar modal menjadi lesu dan harga saham mengalami penurunan. Hal ini bisa berakibat melemahnya indeks Sri Kehati.

H3: BI Rate berpengaruh negatif terhadap indeks harga saham Sri Kehati di Bursa Efek Indonesia periode 2014-2019.

Jumlah uang yang disalurkan bank sentral dan beredar dalam masyarakat (perekonomian) baik uang kertas dan logam disebut jumlah uang beredar. Di saat bank sentral meningkatkan jumlah uang yang diedarkan, maka dana yang dipegang oleh masyarakat akan meningkat. Meningkatnya ketersediaan dana dalam perekonomian modern salah satunya digunakan untuk motivasi spekulasi. Penggunaan uang tunai untuk pembelian surat berharga seperti saham ataupun obligasi merupakan permintaan uang dengan motif spekulasi. Di saat keperluan masyarakat dalam hal konsumsi dan berjaga-jaga sudah terwujud maka sisa dana yang lain dapat digunakan untuk investasi di saham (Andiantyo, et al., 2018). Dengan dana untuk spekulasi yang digunakan membeli saham akan menaikkan harga saham dan indeks harga saham juga bergerak naik (Prahesti \& Parmita, 2020). Hasil penelitian Andiantyo, et al.(2018) menjelaskan bahwa jumlah uang beredar berpengaruh positif pada harga saham. Dengan ketersedian dana untuk motivasi spekulasi meningkat maka memengaruhi peningkatan harga saham. Hal ini dapat terjadi pada peningkatan indeks Sri Kehati.

H4: Jumlah uang beredar berpengaruh positif terhadap indeks harga saham Sri Kehati di Bursa Efek Indonesia periode 2014-2019.

Indeks Shanghai Stock Exhcange ialah sebuah indeks pasar modal yang berada di bursa saham China. Harga saham domestik memiliki hubungan erat dalam kaitannya dengan interaksi bilateral dan perdagangan antar negara. Indonesia dan China sendiri memiliki interaksi bilateral yang erat dan kuat dengan nilai bisnis perdagangan tinggi. Apalagi China merupakan Negara yang memiliki pengaruh besar dalam ekspor dan impor di Indonesia. Pesatnya perkembangan teknologi, menjadikan 
perekonomian semakin terbuka karena kejadian disuatu bursa segera dapat diketahui sehingga memengaruhi bursa lain (Mutakif \& Nurwulandari, 2014). Dengan begitu ketika perekonomian China berada pada kondisi yang bagus maka sentimen pasar juga akan memberikan respon yang tinggi, hal ini juga akan memberikan kondisi yang bagus bagi perekonomian di Indonesia. Melihat kondisi tersebut investor akan menggunakan dananya untuk membeli saham. Dampaknya harga saham meningkat serta indeks harga saham bergerak naik (Prahesti \& Parmita, 2020). Sejalan dengan hasil penelitian Bery \& Worokinasih (2018), Indeks Shanghai berpengaruh positif pada IHSG. Artinya dengan naiknya indeks Shanghai memberi pengaruh dengan naiknya IHSG. Hal ini dapat berpengaruh pada indeks saham tak terkecuali indeks Sri Kehati.

H5: Indeks Shanghai Stock Exchange berpengaruh positif terhadap indeks harga saham Sri Kehati di Bursa Efek Indonesia periode 2014-2019.

\section{METODE PENELITIAN}

Jenis penelitian ini termasuk dalam jenis konklusif berbentuk kausal. Penelitian kausal memiliki tujuan utama mendapatkan data tentang hubungan sebab-akibat (hubungan kausal) (Malhotra, 2009:100). Subjek atau objek yang memiliki karakter dan kualitas tertentu yang telah ditentukan peneliti untuk dipelajari kemudian diambil kesimpulannya disebut populasi (Sugiyono, 2017:80). Data harga penutupan atau closing price bulanan indeks Sri Kehati dalam Bursa Efek Indonesia (BEI) rentang waktu 2014-2019 digunakan sebagai populasi dalam penelitian ini.

Menurut (Sugiyono, 2017:81) komponen karakteristik dan jumlah populasi disebut dengan sampel. Pengambilan sampel mengunakan metode sampling jenuh (sensus) di mana semua anggota populasi diikutsertakan menjadi sampel. Harga penutupan bulanan indeks Sri Kehati digunakan sebagai sampel selama rentang waktu Januari 2014 hingga Desember 2019 sehingga diperoleh total data sampel 72 bulan. Komponen emiten indeks Sri Kehati menyesuaikan hasil evaluasi yang dilakukan dua kali pada bulan April dan Oktober dalam satu tahun. Teknik analisis data yang digunakan dalam penelitian ini adalah analisis regresi linier berganda (multiple linier regression) dengan alat analisis SPSS 2018. Penelitian ini dalam pengumpulan data menggunakan teknik dokumentasi dengan sumber data sekunder, diperoleh dari publikasi web resmi investing.com, badan pusat statistik dan bank Indonesia.

\section{HASIL DAN PEMBAHASAN}

\section{Data Screening}

Screening terhadap data yang akan diolah merupakan langkah awal sebelum melakukan uji statistik. Asumsi bahwa setiap variabel dan seluruh kombinasi linier variabel berdistribusi normal merupakan pengertian Multivariate Normality. Nilai residual juga akan berdistribusi normal jika asumsi multivariate normality terpenuhi (Ghozali, 2013:27).

\section{Hasil Uji Normalitas}

Berdasarkan hasil screening uji normalitas di mana data penelitian yang berjumlah 72 sampel. Setelah dilakukan uji normalitas hasil Asymp.Sig (2-tailed) variabel Sri Kehati 0,352, inflasi 0,290, Kurs 0,703, Indeks Shanghai Stock Exchange 0,118 artinya lebih tinggi nilainya dari 0,05 maka variabel dependen dan independen tersebut datanya terdistribusi normal. Sedangkan variabel BI Rate 0,004 dan variabel JUB 0,000 yang artinya kedua variabel tersebut tidak terdistribusi normal.

\section{Data Outlier}

Sesuai dari data hasil uji normalitas terlihat bahwa terdapat variabel tidak terdistribusi normal yaitu BI Rate dan JUB, sehingga untuk menormalkan kedua variabel maka dilakukan outlier untuk kedua variabel. Dari hasil outlier maka ditemukan 16 data yang di outlier sehingga jumlah data sampel (N) yang diolah menjadi 56. 
Tri Wisnu Hermawan. Analisis Pengaruh Inflasi, Nilai Tukar Rupiah, BI Rate, Jumlah Uang Beredar, dan Indeks Shanghai Stock Exchange terhadap Indeks Sri Kehati di Bursa Efek Indonesia Periode 20142019

\section{Hasil Uji Asumsi Klasik}

Besarnya pembiasan data yang dipakai dalam penelitian dapat diketahui dengan melakukan uji asumsi klasik. Dimaksudkan agar model regresi memenuhi kriteria BLUE (Best Linier Unbiased Estimator).

\section{Hasil Uji Normalitas}

Berdasarkan pengujian K-S menunjukkan hasil uji normalitas didapatkan nilai Asymp.Sig (2-tailed) $0,933>0,05$ menunjukkan data berdistribusi normal.

\section{Hasil Uji Multikolinieritas}

Keseluruhan variabel independen menunjukkan nilai tolerance $>0,10$ dan VIF $<10$ berdasarkan uji multikoliniertias, di antaranya inflasi nilai tolerance 0,927 dan VIF 1,079 , BI Rate nilai tolerance 0,951 dan VIF 1,051, Kurs nilai tolerance 0,904 dan VIF 1,106, JUB nilai tolerance 0,959 dan VIF 1,042, indeks Shanghai Stock Exchange nilai tolerance 0,930 dan VIF 1,075 menunjukkan tidak terindikasi terjadi multikolonieritas.

\section{Hasil Uji Heteroskedastisitas}

Berdasarkan pengujian glejser yang digunakan untuk mengetahui hasil uji heteroskedastisitas menandakan nilai signifikan lebih dari 0,05 artinya indikasi gejala heteroskedastisitas tidak terjadi, di mana nilai signifikan inflasi 0,657, BI Rate 0,272, Kurs 0,417, JUB 0,963, indeks Shanghai Stock Exchange 0,689.

\section{Hasil Uji Autokorelasi}

Berdasarkan pengujian autokorelasi memakai uji Durbin Watson (DW) memiliki nilai 1,805 yang mana nilai ini berada di antara nilai du dan 4-du. Hal ini menandakan autokorelasi positif dan negatif tidak ada pada penelitian ini menunjukkan gejala autokorelasi tidak terjadi.

\section{Hasil Uji Linieritas}

Berdasarkan hasil uji linieritas menggunakan uji Lagrange Multiplier (LM) didapat nilai $\mathrm{R}^{2} 0,345$ dengan jumlah $n=56$ sehingga $c^{2}$ hitung sebesar 19,32 (56 x 0,345), sedangkan $c^{2}$ tabel dengan df 56 dan signifikansi 5\% sebesar 74,468. Perbandingan antara $\mathrm{c}^{2}$ hitung dengan $\mathrm{c}^{2}$ tabel adalah lebih besar $\mathrm{c}^{2}$ tabel sehingga model yang benar dapat dipastikan adalah linier.

\section{Hasil Uji Statistik F}

Berdasarkan hasil uji menunjukan nilai f hitung sebesar 0,001 hasil tersebut membuktikan $\mathrm{H} 0$ ditolak dan Ha diterima di mana 0,001<0,05 yang artinya lebih kecil dari kriteria uji f dan variabel independen nilai tukar rupiah, BI Rate, inflasi, JUB, dan Indeks Shanghai Stock Exchange bersama-sama berpengaruh terhadap variabel dependen yaitu indeks Sri Kehati.

\section{Hasil Uji t}

Berdasarkan uji t nilai signifikansi variabel inflasi $0.043<0.05$ menunjukkan $\mathrm{HO}$ ditolak dan $\mathrm{Ha}$ diterima artinya inflasi berpengaruh positif terhadap indeks Sri Kehati. Nilai signifikansi nilai tukar $0.000<0.05$ menunjukkan H0 diterima dan Ha ditolak artinya nilai tukar tidak berpengaruh positif terhadap indeks Sri Kehati. Nilai signifikansi BI Rate $0.872>0.05$ menunjukkan H0 diterima dan Ha ditolak artinya BI Rate tidak berpengaruh negatif terhadap indeks Sri Kehati. Nilai signifikansi JUB $0.778>0.05$ menunjukkan $\mathrm{H} 0$ diterima dan Ha ditolak artinya jumlah uang beredar tidak berpengaruh positif terhadap indeks Sri Kehati. Nilai signifikansi indeks Shanghai Sock Exchange $0.012<0.05$ menunjukkan H0 ditolak dan Ha diterima artinya indeks Shanghai Stock Exchange berpengaruh positif terhadap indeks Sri Kehati. 
Tabel 2.

HASIL UJI REGRESI LINIER BERGANDA

\begin{tabular}{llcrrr}
\hline Model & \multicolumn{3}{c}{ Unstandardized Coefficients } & \multicolumn{1}{c}{ T } & Sig. \\
& \multicolumn{1}{c}{ B } & \multicolumn{2}{c}{ Std. Error } & & \\
\hline $1 \quad$ Constant) & .008 & & .024 & .352 & .727 \\
& Inflasi (X1) & -.084 & .040 & -2.072 & .043 \\
BI Rate (X2) & .001 & .004 & .162 & .872 \\
Kurs (X3) & -1.066 & .275 & -3.871 & .000 \\
Jub (X4) & .164 & .578 & .284 & .778 \\
Sse (X5) & .200 & .076 & 2.622 & .012 \\
\hline \multicolumn{2}{l}{ Sumber: Output SPSS (2020, data diolah) } & & &
\end{tabular}

Tabel 2 menunjukkan nilai konstanta sebesar 0,008 berarti jika nilai inflasi dan kurs konstan atau sama dengan nol, maka nilai indeks Sri Kehati 0,008. Nilai inflasi -0,084 berarti jika nilai inflasi meningkat 1 satuan, maka nilai indeks Sri Kehati akan mengalami penurunan -0,084 dan Nilai tukar memiliki nilai -1,066 berarti jika nilai tukar meningkat 1 satuan, maka nilai indeks Sri Kehati mengalami penurunan 1,066. Sedangkan indeks Shanghai Stock Exchange memiliki nilai 0,200 berarti bahwa jika nilai indeks Shanghai Stock Exchange meningkat 1 satuan, maka nilai indeks Sri Kehati mengalami peningkatan 0,200 . e adalah error yang berarti bahwa ada variabel independen di luar variabel penelitian yang dapat memengaruhi variabel dependen. Hasil uji regresi linear berganda juga dapat dilihat di rumus (7).

Sri Kehati $=0,008-0,084-1,066+0,200+e$

\section{Koefisien Determinasi}

\section{Tabel 3. \\ HASIL UJI KOEFISIEN DETERMINASI}

\begin{tabular}{ccccc}
\hline Model & R & R Square & Adjusted R Square & Std. Error of the Estimate \\
\hline 1 & .587 & .345 & .279 & .03351 \\
\hline \multicolumn{4}{l}{ Sumber: Output SPSS (2020, data diolah) }
\end{tabular}

Tabel 3. Diketahui nilai Adjusted $\mathrm{R}^{2}$ 27,9\% variabel indeks Sri Kehati dipengaruhi inflasi, nilai tukar rupiah, BI Rate, JUB, dan indeks Shanghai Stock Exchange. Sisanya 72.1\% dijelaskan variabel di luar penelitian ini yang dapat memengaruhi indeks Sri Kehati.

\section{Pengaruh Inflasi terhadap Indeks Sri kehati}

Berdasarkan hasil analisis menunjukkan inflasi memiliki pengaruh terhadap indeks Sri Kehati pada periode 2014-2019, selaras dengan hipotesis pertama sehingga hipotesis pertama yang diusulkan diterima. Sesuai penelitian Manurung (2016) secara parsial bahwa inflasi berpengaruh negatif dan signifikan terhadap IHSG, karena barang-barang di pasar yang secara signifikan mengalami kenaikan disebabkan tingginya tingkat inflasi, akibatnya masyarakat memiliki daya beli yang rendah, dampaknya profit perusahaan menurun. Para pemegang saham akan menerima pembagian deviden yang lebih sedikit, pembagian dividen yang sedikit ini menyebabkan kecenderungan investor melakukan penanaman modal di pasar uang dibanding di pasar modal. Hal tersebut mengakibatkan turunnya Indeks Sri Kehati.

Implikasi praktis dari hasil penelitian ini adalah inflasi disarankan dijadikan acuan bagi investor ketika ingin berinvestasi saham, di saat tingkat inflasi mengalami kenaikan maka akan mengakibatkan turunnya Indeks Sri Kehati, sebaliknya di saat tingkat inflasi menurun maka akan mengakibatkan naiknya indeks Sri Kehati. 
Tri Wisnu Hermawan. Analisis Pengaruh Inflasi, Nilai Tukar Rupiah, BI Rate, Jumlah Uang Beredar, dan Indeks Shanghai Stock Exchange terhadap Indeks Sri Kehati di Bursa Efek Indonesia Periode 20142019

\section{Pengaruh Nilai Tukar Rupiah terhadap Indeks Sri Kehati}

Berdasarkan hasil analisis menandakan nilai tukar mempunyai pengaruh terhadap Indeks Sri Kehati pada rentang waktu 2014-2019, tidak selaras dengan hipotesis kedua sehingga hipotesis yang diusulkan ditolak. Tetapi hasil penelitian sama dengan penelitian Widyasa \& Worokinasih (2018). Pengaruh negatif nilai tukar rupiah terhadap dollar dapat dikarenakan menguatnya nilai tukar rupiah terhadap dollar. Menguatnya rupiah terhadap dollar menjadikan pendapatan perusahaan yang sering melakukan kegiatan ekspor menjadi berkurang. Laba perusahaan yang berkurang berpotensi menyurutkan minat investor dalam berinvestasi saham, pada akhirnya menjadikan pergerakan indeks harga saham turun.

Implikasi praktisnya adalah sebaiknya nilai tukar rupiah dijadikan investor sebagai acuan ketika ingin berinvestasi saham, karena fluktuasi yang terjadi pada nilai tukar rupiah dapat memengaruhi Indeks Sri Kehati.

\section{Pengaruh BI Rate terhadap Indeks Sri Kehati}

Berdasarkan hasil analisis menandakan BI Rate tidak berpengaruh terhadap Indeks Sri Kehati pada rentang waktu 2014-2019. Hasil ini tidak sama dengan hipotesis peneliti bahwa BI Rate berpengaruh negatif terhadap Indeks Sri Kehati. Tetapi hasilnya sama dengan studi Zabidi \& Asandimitra (2018). Tidak berpengaruhnya BI Rate dikarenakan bagi masyarakat BI Rate belum menjadi parameter instrumen investasi untuk dijadikan pedoman. BI Rate tidak berpengaruh terhadap indeks harga saham dikarenakan penanam modal di Indonesia cenderung melakukan aksi jual saham dengan harga tinggi dari harga belinya dengan maksud mendapat keuntungan dari margin harga beli dan harga jual, ini merupakan tipe transaksi saham penanam modal jangka pendek (Silim, 2013).

Implikasi praktis dari hasil penelitian ini adalah dalam berinvestasi saham sebaiknya BI Rate tidak dijadikan bahan pertimbangan atau acuan bagi investor sebab menurut hasil penelitian ini BI Rate tidak memberikan pengaruh terhadap indeks Sri Kehati. Maka dari itu saat BI Rate mengalami kenaikan atau penurunan tidak memberikan dampak terhadap indeks Sri Kehati.

\section{Pengaruh Jumlah Uang Beredar terhadap Indeks Sri Kehati}

Berdasarkan hasil analisis menandakan jumlah uang beredar tidak berpengaruh terhadap indeks Sri Kehati pada rentang waktu 2014-2019. Hasilnya tidak sama dengan hipotesis peneliti bahwa jumlah uang beredar berpengaruh positif terhadap indeks Sri Kehati. Tetapi hasil ini sesuai dengan penelitian Kusuma \& Badjra (2016) di mana terjadi peningkatan yang didominasi kewajiban bea bunga simpanan tinggi yang dikapitalisasi dan perluasan wilyah beberapa elemen tagihan bersih utamanya pembayaran dalam rangka kegiatan penjaminan terhadap kewajiban perbankan dan pembayaran kupon obligasi rekapitalisasi bank kepada pemerintah yang menjadikan jumlah uang beredar tidak berpengaruh. Peningkatan jumlah uang beredar yang dipegang masyarakat benar-benar sangat kecil dan tidak mempengaruh kenaikan harga saham sama sekali karena tidak ada penambahan uang di masyarakat untuk berinvestasi di pasar modal (Kusuma \& Badjra, 2016).

Implikasi praktis hasil penelitian ini adalah jumlah uang beredar tidak disarankan bagi investor sebagai acuan atau bahan pertimbangan dalam berinvestasi saham sebab menurut hasil penelitian ini jumlah uang beredar tidak berdampak terhadap indeks Sri Kehati. Maka dari itu saat terjadi peningkatan jumlah uang beredar di masyarakat dampaknya tidak signifikan terhadap indeks Sri Kehati.

\section{Pengaruh Indeks Shanghai Stock Exchange terhadap Indeks Sri Kehati}

Berdasarkan hasil analisis menunjukkan indeks Shanghai Stock Exchange memiliki pengaruh terhadap indeks Sri Kehati pada periode 2014-2019, hal ini selaras dengan hipotesis kelima oleh karena itu hipotesis yang diusulkan diterima. Sesuai dengan studi Bery \& Worokinasih (2018). Signifikannya hubungan antara indeks Shanghai Stock Exchange dengan indeks Sri Kehati menunjukkan bahwa para investor sangat memperhatikan indeks regional yaitu indeks Shanghai Stock Exchange jika hendak berinvestasi di pasar modal. Diketahui hasil koefisien regresi bernilai positif yang mengandung arti bahwa setiap peningkatan indeks Shanghai Stock Exchange maka indeks Sri Kehati juga akan meningkat. Berpengaruhnya indeks Shanghai Stock Exchange terhadap indeks Sri Kehati dikarenakan 
China dan Indonesia memiliki hubungan kerja sama ekspor dan impor dengan nilai yang besar. Indeks Shanghai Stock Exchange semakin berpengaruh terhadap indeks Sri Kehati dikarenakan semakin berkembangnya hubungan antara Indonesia-China penandatanganan ASEAN-China Free Trade Agreement (ACFTA) pada tahun 2010 (Bery \& Worokinasih, 2018).

Implikasi praktis dari hasil penelitian ini adalah investor disarankan menjadikan pergerakan indeks Shanghai Stock Exchange sebagai pedoman atau bahan pertimbangan sebagai sumber informasi saat ingin berinvestasi saham agar memperoleh portofolio optimal dan dapat meminimalisir risiko yang ada karena indeks Shanghai Stock Exchange memiliki pengaruh signifikan positif terhadap indeks Sri Kehati, di saat pergerakan indeks Shanghai Stock Exchange membaik akan diikuti juga oleh indeks Sri Kehati, begitupun sebaliknya. Oleh sebab itu, penting bagi investor untuk selalu memantau bagaimana laju indeks Shanghai Stock Exchange dan berbagai informasi mengenai indeks Shanghai Stock Exchange jika ingin membeli saham indeks Sri Kehati.

\section{KESIMPULAN}

Kesimpulan berlandaskan pada hasil analisis dan uraian yang telah dijelaskan variabel indeks Shanghai Stock Exchange, jumlah uang beredar, nilai tukar, BI rate dan inflasi bersama-sama berpengaruh terhadap indeks Sri Kehati. Secara parsial variabel yang berpengaruh signifikan negatif terhadap indeks Sri Kehati yaitu nilai tukar dan inflasi. Sedangkan variabel indeks Shanghai Stock Exchange berpengaruh positif terhadap indeks Sri Kehati, serta variabel yang tidak berpengaruh terhadap indeks Sri Kehati yaitu BI rate dan jumlah uang beredar.

Penelitian selanjutnya dapat melibatkan variabel-variabel indeks global seperti indeks Dow Jones dan variabel makro lainnya seperti PDB atau menggunakan indeks yang dipengaruhi saham-saham berkapitalisasi besar lainnya seperti Kompas100, IDX30 dan LQ45. Bagi investor disarankan untuk memperhatikan pergerakan inflasi, nilai tukar, dan indeks Shanghai Stock Exchange sebelum berinvestasi karena dalam penelitian ini.

\section{DAFTAR PUSTAKA}

Andiantyo, P., Sihombing, P., \& Kusumastuti, S. Y. (2018). Pergerakan Indeks Harga Saham Sektor Pertanian Di Bursa Efek Indonesia. Prosiding Seminar Nasional Cendekiawan, O(0), 1137-1148. https://www.trijurnal.lemlit.trisakti.ac.id/semnas/article/view/3488

Anggraini, F. N., \& Nurhadi. (2019). Indeks Dow Jones Industrial Average (DJIA), Indeks Shanghai Stock Exchange (SSE), Kurs USD/IDR Dan BI Rate Berpengaruh Terhadap Indeks Harga Saham Gabungan (IHSG) Di Bursa Efek Indonesia (BEI) Periode 20152018. Jurnal Bisnis Indonesia, 10(1), 57-69.

Bery, D., \& Worokinasih, S. (2018). Pengaruh Indeks Harga Saham Global Terhadap Indeks Harga Saham Gabungan ( IHSG ) ( Studi Pada Bursa Efek Indonesia Periode 2014-2017 ). Jurnal Administrasi Bisnis (JAB), 64(1), 126-135.

BPS. (2020a). Uang Beredar (Miliar Rupiah), 2003 - 2020. Bps.Go.Id. https://www.bps.go.id/dynamictable/2015/12/22/1074/uang-beredar-miliar-rupiah-20032017.html. Diakses pada 21 Juli 2020).

BPS. (2020b). Volume Ekspor Menurut Negara Tujuan Utama (Berat bersih: ribu ton), 20002018. Bps.Go.Id. https://www.bps.go.id/statictable/2014/09/08/1009/volume-ekspormenurut-negara-tujuan-utama-berat-bersih-ribu-ton-2000-2018.html. Diakses pada 21 Jui 2020). 
Tri Wisnu Hermawan. Analisis Pengaruh Inflasi, Nilai Tukar Rupiah, BI Rate, Jumlah Uang Beredar, dan Indeks Shanghai Stock Exchange terhadap Indeks Sri Kehati di Bursa Efek Indonesia Periode 20142019

BPS. (2020c). Volume Impor Menurut Negara Asal Utama (Berat bersih:ribu ton), 2000-2019. Bps.Go.Id. https://www.bps.go.id/statictable/2014/09/08/1035/volume-impor-menurutnegara-asal-utama-berat-bersih-ribu-ton-2000-2019.html. Diakses pada 21 Juli 2020).

CRMS. (2020). Mengenal Indeks Keberlanjutan Perusahaan Dari Sri-Kehati. Crmsindonesia.Org. https://crmsindonesia.org/publications/mengenal-indekskeberlanjutan-perusahaan-dari-sri-kehati/. Diakses pada 4 Maret 2019).

Detikfinance. (2014). IHSG Tumbuh 21,15\% Di 2014, Tertinggi Keempat Di Dunia. Detikfinance. https://finance.detik.com/bursa-dan-valas/d-2790227/ihsg-tumbuh-2115di-2014-tertinggi-keempat-di-dunia. Diakses pada 3 Maret 2019).

Fordian, D. (2016). The Effect Of Macro-Economic And Presidential Elections To Jakarta Composite Index On Indonesia Stock Exchange: Study Period 2012 - 2016. Jurnal Adbispreneur, 1(3), 267-277.

Ghozali, I. (2013). Aplikasi Analisis Multivariete. Badan Penerbit Universitas Diponegoro.

Haider, S. W. (2018). Impact of Interest Rate, Inflation Rate, Exchange Rate and Gold Prices on Karachi Meezan Index 30. European Journal of Islamic Finance, 10, 0-8. https://doi.org/10.13135/2421-2172/2584

IDX. (2018). Indeks Saham. Idx.Co.Id. https://www.idx.co.id/produk/indeks/. Diakses pada 3 Juli 2020).

Kehati, Y. (2020). Index Sri-Kehati. Kehati.or.Id. https://www.kehati.or.id/index-sri-kehati/. Diakses pada 3 Maret 2019).

Kusuma, I., \& Badjra, I. (2016). Pengaruh Inflasi, Jub, Nilai Kurs Dollar Dan Pertumbuhan Gdp Terhadap Ihsg Di Bursa Efek Indonesia. E-Jurnal Manajemen Universitas Udayana, 5(3), 255199.

Kusumawati, D. A., \& Asandimitra, N. (2017). Impact of Global Index , Gold Price and Macro Economic Variable for Indonesia Impact of Global Index, Gold Price and Macro Economic Variable for Indonesia Composite Index. Journal of Finance and Accounting, $8(2)$.

Lusiana, O. A. (2020). Analisis Pengaruh Inflasi, SBI, Kurs Dan Indeks Global Terhadap Pergerakan Indeks Harga Saham Di BEI Pada Periode 2016-208. Jurnal Ilmu Manajemen (JIM), 8(November 2016), 210-224.

Maimuna, I. (2017). Pengaruh Tingkat Inflasi, Nilai Tukar Rupiah Dan Suku Bunga Sertifikat Bank Indonesia Terhadap Indeks Harga Saham Gabungan Pada Bursa Efek Indonesia. Eprints.Perbanas.Ac.Id. https://doi.org/10.1017/CBO9781107415324.004

Malhotra, N. (2009). Riset Pemasaran: Pendekatan Terapan. PT Indeks.

Manurung, R. (2016). Pengaruh Inflasi, Suku Bunga dan Kurs terhadap Indeks Harga Saham Gabungan pada Bursa Efek Indonesia. Jurnal Ekonomi, 19(4), 148-156.

Mutakif, F., \& Nurwulandari, A. (2014). Pengaruh Volume Perdagangan Saham, Nilai Tukar 
Dan Indeks Hang Seng Terhadap Pergerakan Indek Harga Saham Gabungan. Jurnal Akuntansi Dan Bisnis, 7(2), 178-192.

Nijam, H., Ismail, S., \& Musthafa, A. (2015). The Impact of Macro - Economic Variables on Stock Market Performance; Evidence From Sri Lanka. Journal of Emerging Trends in Economics and Management Sciences ( JETEMS ), 6(2), 151-157.

Otorima, M., \& Kesuma, A. (2016). Pengaruh Nilai Tukar, Suku Bunga, Inflasi, Jumlah Uang Beredar Dan Pdb Terhadap Indeks Harga Saham Gabungan (Ihsg) Periode 2005-2015. Jurnal Terapan Manajemen Dan Bisnis, 2(2), 12-24.

Prahesti, S., \& Parmita, R. . (2020). Pengaruh Indeks SSEC, N225, STI, Dan Faktor Makroekonomi Terhadap IHSG. Jurnal Ilmu Manajemen (JIM), 8(2019), 878-893.

Puspita, M. D., \& Aji, T. S. (2018). Analisis Pengaruh Inflasi, Suku Bunga SBI, Nilai Tukar, Produk Domestik Bruto (PDB) dan Indeks Dow Jones Industrial Average (DJIA) Terhadap Indeks Kompas100 Periode Januari 2012-Desember 2017. Jurnal Ilmu Manajemen (JIM), 6(3), 333-341.

Putri, K. T. R., Darmawan, N. A. S., \& Sulindawati, N. L. G. E. (2015). Pengaruh Tingkat Suku Bunga SBI, Kurs Mata Uang Rupiah Atas Dollar As, dan Indeks Dow Jones Terhadap Indeks Harga Saham Gabungan (IHSG) Pada Bursa Efek Indonesia (BEI). EJournal S1 Universitas Pendidikan Ganesha, 3(1).

Qurochman, A. N. (2017). Pengaruh Inflasi, Jumlah Uang Beredar, Kurs Rupiah Dan Neraca Perdagangan Indonesia Terhadap Indeks Sri Kehati Di BEI. Jurnal Mapan STIE Yapan Surabaya, 2(2), 8-17.

Robiyanto, \& Hartanto, A. F. (2018). Contagion Effect Dan Integrasi Pasar Modal Di Kawasan Asia, Eropa Dan Amerika. Jurnal Organisasi Dan Manajemen, 14(1), 1-9.

Samsul, M. (2006). Pasar Modal dan Manajemen Portofolio. Erlangga.

Samuelson, P., \& Nordhaus, W. . (2004). Ilmu Makroekonomi. PT Media Global Edukasi.

Sari, A. N. P. (2015). Pengaruh Tingkat Inflasi, Suku Bunga SBI, Dan Nilai Tukar Rupiah Pada US Dollar Terhadap Pergerakan Indeks Harga Saham Gabungan Perusahaan Manufaktur Yang Terdaftar Pada Bursa Efek Indonesia Periode Tahun 2010-2013. Eprints.Dinus.Ac.Id, 1-23.

Silim, L. (2013). Pengaruh Variabel Ekonomi Makro Terhadap Indeks Harga Saham Gabungan Pada Bursa Efek Indonesia Periode 2002-2011. Ilmiah Mahasiswa Universitas Surabaya, 2(2), 1-18.

Sugiyono. (2017). Metode Penelitian: Kuantitatif, Kualitatif, dan R\&D. Alfabeta.

Sukirno, S. (2010). Makroekonomi Teori Pengantar. Rajawali Pers.

Suriyani, N. K., \& Sudiarta, G. M. (2018). Pengaruh Tingkat Suku Bunga, Inflasi Dan Nilai Tukar Terhadap Return Saham Di Bursa Efek Indonesia. E-Jurnal Manajemen Unud, 7(6), 3172-3200. 
Tri Wisnu Hermawan. Analisis Pengaruh Inflasi, Nilai Tukar Rupiah, BI Rate, Jumlah Uang Beredar, dan Indeks Shanghai Stock Exchange terhadap Indeks Sri Kehati di Bursa Efek Indonesia Periode 20142019

Tandelilin, E. (2010). Portofolio Dan Investasi : Teori Dan Aplikasi (Pertama). Kanisius.

Utami, A. T., \& Herlambang, L. (2016). Pengaruh variabel makro ekonomi terhadap indeks Jakarta Islamic Index (JII) periode januari 2010 hingga november 2015. Jurnal Ekonomi Syariah Teori Dan Terapan, 3(1), 70-84.

Wannabe, F. (2012). Saham Ramah Lingkungan. Fiscuswannabe.Web.Id. (https://www.fiscuswannabe.web.id/2012/07/indeks-sri-kehati.html. Diakses pada 28 Juli 2020).

Widyasa, V. I. A., \& Worokinasih, S. (2018). Pengaruh Tingkat Inflasi, Nilai Tukar Rupiah, dan Tingkat Suku Bunga Terhadap Indeks Saham Syariah Indonesia (ISSI) (Studi Pada Saham Syariah Yang Terdaftar Di Bursa Efek Indonesia Periode 2013-2017). Jurnal Administrasi Bisnis (JAB), 60(1), 119-128.

Yulianti, M. T., \& Purwohandoko. (2019). Pengaruh Variabel Makroekonomi, Harga Komoditas \& Indeks Saham Global Terhadap IHSG Periode 2014-2018. Jurnal Ilmu Manajemen (JIM), 7(3), 629-641.

Zabidi, I. I., \& Asandimitra, N. (2018). Pengaruh Inflasi, Kurs, Suku Bunga Sbi, Dow Jones, Dan Nikkei 225 Terhadap Indeks Harga Saham Gabungan Pada Bursa Efek Indonesia Periode 2012-2016. Jurnal Ilmu Manajemen (JIM), 6(4), 468-476. 